\title{
Needs of Flight Telecommunication Personnel in Airnav Madya Kualanamu Branch Based on Work Loads
}

\author{
Rossi Peter Simanjuntak ${ }^{1 *}$, Susi Diriyanti ${ }^{2}$ \\ ${ }^{1,2)}$ Aviation Engineering and Safety Academy, Medan, Indonesia \\ *rossi_juntak@yahoo.com
}

\begin{abstract}
Airnav Indonesia Madya Kualanamu Branch as a provider of flight navigation services. The company has modernized CNSA (Communication, Navigation, Surveillance, Automation, Aeronautical Information System) facilities and system systems as well as adequate flight procedures. Aviation Telecommunications personnel are responsible for planning, preparing, operating and maintaining CNSA facilities and systems. The workload of personnel in maintaining facilities is the basis for calculating personnel requirements for maintenance. Airport operating hours are used to calculate the needs of personnel for shift service. The method used to calculate the number of aviation telecommunications personnel is based on the Director General of Civil Aviation Regulation Number: KP 25 of 2014 so as to obtain the need for personnel for maintenance totaling 7 (seven) people and the need for personnel for rotating service totaling 8 (eight) people per shift.
\end{abstract}

Keywords: workload, aviation, communication, navigation, surveillance, automation,

\section{Introduction}

The aviation world in Indonesia which is developing quite rapidly requires companies to move quickly and flexibly in responding to improved services to clients, particularly flight safety and security. One of the steps taken by the company in order to suppress the factors that hinder the company's operations to achieve its goals is that proper business management is needed. One business management that needs attention is human resource management.

Mangkunegara [1] human resource management is planning, organizing, coordinating, implementing and supervising the procurement, development, remuneration, integration, maintenance and separation of the workforce in order to achieve organizational goals. Management and organization of human resources such as planning, procurement, maintenance, guidance, development and utilization as well as possible will produce quality human resources.

Human resource management plays an important role in managing all human resources so that they can work effectively and efficiently so that they are required to be able to share the workload and responsibilities of each employee, conduct work evaluations, conduct training in order to develop employees, and also provide rewards in a manner just and equitable.

Workload is a group or a number of activities that must be completed by an organizational unit or position holder within a certain period. Workload measurement is defined as a technique for obtaining information about the efficiency and effectiveness of the work of an 
organizational unit, or position holders carried out systematically using job analysis techniques, workload analysis techniques or other management techniques [2].

AirNav Indonesia has several branches, one of them is Airnav intermediate branch Kualanamu. Airnav intermediate branch of Kualanamu has a commitment to improve the service and safety of the aviation world so as to increase the confidence of the public and the international world in Indonesian aviation navigation. In order to maintain service quality it is important to maintain and improve the quality and quantity of production equipment utilities such as telecommunications, navigation, surveillance, automation, aeronautical systems, technical support equipment and towers. To plan, operate and maintain the equipment needed human resources who possess competencies according to their fields, one of them is aviation telecommunications personnel.

\section{Research Method}

In determining the amount of time needed to carry out equipment maintenance, a survey of current personnel is conducted. The number of samples taken in this study uses a simple random sampling size formula to estimate the proportion of a population as follows:

$$
n=\frac{N * Z_{1-\alpha / 2}^{2} * p * q}{(N-1) * d^{2}+Z_{1-\alpha / 2}^{2} * p * q}
$$

Where :

$$
\begin{array}{ll}
\mathrm{N} & : \text { number of samples needed } \\
\mathrm{N} & : \text { total population } \\
\mathrm{Z} & : \text { The default value of the normal distribution at a certain } \alpha \\
\mathrm{p} & : \text { proportion of personnel } \\
\mathrm{q} & : \text { 1-p } \\
\mathrm{d} & : \text { degree of accuracy (precision) that is desired }
\end{array}
$$

This type of research is descriptive by analyzing quantitative data, where the time required for personnel to maintain equipment is used as a personnel workload that will be compared with the effective hours of personnel per year so that the number of personnel needed to maintain existing equipment will be obtained.

According to Ilyas $[3,4]$, the formula for calculating workload of units or personnel per day is as follows:

Workload $/$ day $=$ B.Ki-j $=$ JT $x$ W.T

Information:

B. Ki-j: type of workload

JT: number of transactions per day

W.T: Time (minutes or hours) of each type of transaction

For the needs of rotating service personnel use the data of operating hours of service providers per year. The office hours will be compared with the effective working hours of personnel per year. After obtaining the number of rotating personnel added with 1 (one) shift standby. 


\section{Results and Discussion}

From the calculations carried out it was found that the need for personnel for maintenance as many as 7 people. Your airline's operational hours for 24 hours so that for personnel needs for rotating service is airport operating hours $>12$ hours $=3$ shifts +1 shift standby. The number of personnel needed per shift is 8 people. The number of airline telecommunications personnel needs at Airnav your intermediate branch is 39 people.

In carrying out aviation telecommunications services at AirNav Kualanamu Branch, the organization and human resources needed to run an organization related to aviation telecommunications services are as follows:

1) Technical Manager

2) 2nd Engineering Supervisor CNS \& Otomasi

3) 2nd Technician CNS \& Otomasi

4) 3rd Technician CNS \& Otomasi

5) 4th Technician CNS \& Otomasi

Broadly speaking, the main tasks and authority of aviation telecommunications personnel is to plan, maintain and operate communications and / navigation equipment and / flight observation equipment

Based on KP.25 of 2014 in determining the number of aviation telecommunications technicians in a flight navigation service provider based on 2 (two) criteria, namely:

\section{The need for technicians for equipment maintenance}

In accordance with the number of equipment in the service provider can be grouped into groups of equipment and from the group of equipment can be calculated Allotment Hours for each year. The calculation of allotment hours is calculated according to No. SKEP / 157 / IX / 2003 of the number of daily, weekly, monthly, semester, and yearly maintenance for each equipment.

From the number of Allotment Hours divided by the number of individual effective work per year produced the number of technicians for maintenance.

The number of effective individual working hours per year, namely:

1 (one) week

$=8$ hours $\times 5$ days $\quad=40$ hours

1 (one) year

$=40$ hours $\times 52$ weeks $=2080$ hours

Deduction in one year, namely:

2 (two) weeks annual leave

12 (twelve) days

$=8$ hours $\times 10$ days $\quad=80$ hours

1 (one) week due to illness

$=8$ hours $\mathrm{x} 12$ days

$=96$ hours

Training courses

$=8$ hours $\times 5$ days

$=40$ hours

Preparation Time 10 minutes / day

$=100$ hours

60 minute rest / day

$=35$ hours

Time for prayer (including Friday prayers)

$=365$ hours

Time for vehicle preparation, equipment, travel time, etc.

Total

So the individual effective working hours / year $=2,080-1039$

$=115$ hours

$=208$ hours

$=1039$ hours

$=1041$ hours 


\section{The Need for Technicians for Shift (Shift) Service}

Operating hours for service providers refer to the Director General of Hubud's Skep No. 45 of 2005 concerning Airport Operational Hours. So for the needs of rotating service divided into 3 groups, namely:

a. Airport operating hours $\leq 7$ hours $/$ day $=1$ shift +1 shift standby

b. Airport operating hours $>7 / \mathrm{d}<12$ hours / day $=2$ shifts +1 shift standby

c. Airport operating hours $>12$ hours $=3$ shifts +1 shift standby

For aviation telecommunications technicians to be on standby within 24 hours, three shifts in shift service +1 Shift Standby are set. So the need for technicians for rotating service is the number of operating shifts and standby shifts multiplied by the number of personnel per shift, then added to the lead [6,7]. But for the status of the service provider as en route plus 1 person.

\section{Total Need for Aviation Telecommunications Technicians}

The total need for aviation telecommunications technicians is the number of technicians for maintenance plus the number of technicians for the shift service. In calculating the amount of workload of personnel can be calculated based on the amount of equipment available and the time needed to complete maintenance tasks performed by personnel both daily, weekly, quarterly, semester and yearly $[8,9]$.

\section{References}

[1] Mangkunegara, A.P. (2017), Manajemen Sumber Daya Manusia Perusahaan. Bandung : PT. Remaja Rosdakarya.

[2] Dhania, Dhini Rama. (2010), Pengaruh Stres Kerja, Beban Kerja Terhadap Kepuasan Kerja (Studi Pada Medical Representatif Di Kota Kudus). Jurnal Psikologi Universitas Muria Kudus, . I (1).

[3] Helianty, Yanti. (2014), Analisis Kebutuhan Jumlah Pegawai Berdasarkan Analisis Beban Kerja. Teknik Industri Itenas, 4(1).

[4] Hidayat, T.Fariz, Sugiharto Pujangkoro, Anizar. (2013), Pengukuran Beban Kerja Perawat Menggunakan Metode Nasa-Tlx Di Rumah Sakit Xyz. e-Jurnal Teknik Industri FT USU, 2(1)

[5] Hima, Amalia Faikhotul dan Mahrus Khoirul Umami. (2011), Evaluasi Beban Kerja Operator Mesin pada Departemen Log and Veeeneer Preparation di PT. XYZ. Jurnal Teknik dan Manajemen Industri, 6(2).

[6] KP 35 (2019). Kementerian Perhubungan. Direktorat Perhubungan Udara

[7] Keputusan Menteri Aparatur Negara RI, No. KEP/75/M.PAN/2004 tentang Pedoman Perhitungan Kebutuhan Pegawai Berdasarkan beban Kerja dalam Rangka Penyusunan Formasi Pegawai Negeri Sipil. Jakarta: KemenPAN RI, (2004).

[8] Ramadhan, Muhammad Rizky, Yoanita Yuniati, Sugih Arijanto. (2014). Analisis Beban Kerja Dan Pengukuran GAP Kompetensi Teknisi Laboratorium Umum Dan Fakultas Z PTS XYZ. Jurusan Teknik Industri Itenas, 3 (2).

[9] Ronald E Walpole, Raymond H Myers. (1986), Ilmu Peluang dan Statistik untuk Insiyur dan Ilmuan. Bandung : Penerbit ITB. 